Available online at: https://proceeding.researchsynergypress.com/index.php/rsfconferenceseries1

RSF Conference Series: Business, Management and Social Sciences

e-ISSN 2807-5803/ p-ISSN 2807-6699

Volume 1 Number 3 (2021): 115-122

\title{
The Effect of Economic Digitization on Financial Inclusion and International Trade in Southeast Asia
}

\author{
Rini Dwi Astuti' ${ }^{1}$, Purwiyanta ${ }^{1}$ \\ ${ }^{1}$ Faculty of Economics and Business, Universitas Pembangunan Nasional “Veteran” Yogyakarta, \\ Indonesia
}

\begin{abstract}
The rapid development of information technology has made economic digitization a necessity throughout the world, including Southeast Asia. This study aims to analyze the effect of economic digitization on financial inclusion and international trade using the Vector Autoregression Model analysis tool for ten countries in ASEAN for the 2017-2019 period. The results showed that international trade and financial inclusion variables could respond quickly to shocks in the variable of economic digitization. Economic growth can respond quickly to shocks in global trade variables and financial inclusion variables. There is no causal relationship between economic growth and international trade. However, there is a one-way causality relationship between economic growth and financial inclusion, where inclusion affects economic growth but not vice versa.
\end{abstract}

Keywords: economic digitization, financial inclusion, international trade, vector autoregression model

This is an open access article under the CC-BY-NC license

\section{INTRODUCTION}

The digital economy is changing the global economy, enabling small industries to become global micro industries with their elasticity and dynamics. This digital economy can give startups a higher chance of being born globally; digitalization drives competition, enabling innovative business models and allowing companies to scale up quickly. Tens of millions of small and medium-sized companies worldwide have turned into exporters, joined the e-commerce market, and competed with the largest multinational companies (Ahmedov, 2020). Technology drives down prices and increases efficiency and productivity in the long run. With technology, the economy is growing faster through lower costs of communication and transportation, more effective global supply, and the formation of new global markets (Ciuriak \& Ptashkina, 2018).

Information and Communication Technology (ICT) is growing along with the science and development of human civilization. The era of globalization seems evident with the ease of digital access in various parts of the world. Developing countries, which are often seen as of late and backward are, in fact quite quick to respond to the development of ICT (Myovella et al., 2020). ICT can bring developing countries into developed countries with a collective movement so that benefits can be obtained optimally (Semyachkov, 2019). 
Table 1. Economic Digitization in Southeast Asia in 2019

\begin{tabular}{|l|c|c|c|}
\hline \multicolumn{1}{|c|}{ Countries } & $\begin{array}{c}\text { Number of internet } \\
\text { users (percent) }\end{array}$ & $\begin{array}{c}\text { Number of social } \\
\text { media users } \\
\text { (million) }\end{array}$ & $\begin{array}{c}\text { Average internet } \\
\text { network speed } \\
\text { (MBps) }\end{array}$ \\
\hline Brunei Darussalam & 95 & 0.41 & 20.98 \\
\hline Cambodia & 58 & 9.7 & 20.89 \\
\hline Indonesia & 64 & 160 & 20.11 \\
\hline $\begin{array}{l}\text { Lao People's } \\
\text { Democratic } \\
\text { Republic }\end{array}$ & 43 & 3.1 & 34.48 \\
\hline Malaysia & & & 78.03 \\
\hline Myanmar & 83 & 26 & 18.9 \\
\hline Philippines & 41 & 22 & 25.55 \\
\hline Singapore & 67 & 73 & 200.12 \\
\hline Thailand & 88 & 4.6 & 125.12 \\
\hline Vietnam & 75 & 52 & 43.26 \\
\hline
\end{tabular}

Source: www.worlbank.org

In Southeast Asia, developed countries such as Brunei and Singapore have the highest number of internet users at 95 percent and 88 percent, respectively, in contrast to Lao and Myanmar, which are only around 40 percent. Indonesia has very extreme active social media users compared to other countries in Southeast Asia, which reached 160 million users, while in Brunei, it was only 0.41 million users (Table 1). It is interesting to conduct research related to the effect of digitalization on international trade and financial inclusion to encourage higher economic growth.

\section{LITERATURE REVIEW}

The industrial revolution 4.0 gave new terminology in the financial world, widely known as the Digital Economy. The digital economy is a social phenomenon that affects the economic system, where this phenomenon has characteristics as an intelligence room, including information, various access to information instruments, information capacity, and information processing (Pereira \& Romero, 2017). The use of information and communication technology (ICT) can increase productivity by maximizing its effect on economic growth (Bilozubenko et al., 2020). ICT is gradually becoming one of the main factors of socioeconomic progress, causing structural and institutional changes (Njoh, 2018; Wang, 2021). The widespread use of ICTs in the economy led to the formation of the structure and make transitions toward digital economy (Pereira \& Romero, 2017) and is a momentum to modernize the economic system and extract additional opportunities for intensification (Amuso et al., 2019).

Digital finance has a two-way causal relationship with financial inclusion. The development of digital finance will make everyone interested in using digital financial services and persuade friends or family who incidentally do not have an excellent financial understanding to access financial services. Greater financial inclusion can result in more excellent digital finance. Increasing the number of flawed or low-income individuals with savings or checking accounts at formal banking institutions makes it easier for banks to inform or persuade new and existing account holders about products and services. Available digital financial services that they can use for their convenience.

The digital era brings major impacts and changes in international trade in the future. Digital commerce is part of the digital revolution that will have a very wide impact on the whole world. In the era of digital trade, trading partners will increasingly demand the application of the principles of openness and non- 
discrimination in global data traffic. Policymakers are required to fully facilitated digital trade transactions by providing the most conducive regulatory framework so as not to hinder its growth rate.

\section{RESEARCH METHOD}

The analytical tool used in this research is Vector Autoregressive (VAR). This dynamic equation system is a multivariate forecasting model that is used to construct a forecasting system from interrelated time series data and to analyze the dynamic effects of the presence of random factors that interfere with the system (Gujarati \& Porter, 2009; Gujarati, 2012).

The models used in this study are:

$$
\begin{gathered}
I K=\sum_{i=1}^{n} \alpha_{i} E D 1_{t-i}+\sum_{j=1}^{n} \alpha_{j} E D 2_{t-j}+\sum_{k=1}^{n} \alpha_{k} E D 3_{t-k}+e_{t} \\
\text { TRADE }=\sum_{i=1}^{n} \beta_{i} E D 1_{t-i}+\sum_{j=1}^{n} \beta_{j} E D 2_{t-j}+\sum_{k=1}^{n} \beta_{k} E D 3_{t-k}+e_{t} \\
\text { GROWTH }=\sum_{i=1}^{n} \gamma I K_{t-i}+\sum_{j=1}^{n} \gamma_{j} T R A D E_{t-j}+\sum_{k=1}^{n} \gamma_{k} E D_{t-k}+e_{t}
\end{gathered}
$$

Financial inclusion (IK) is measured by the ratio of money area (M2) to GDP in units percent, international trade (TRADE) is measured by the ratio of exports plus imports to GDP in percent, economic growth (GROWTH) is measured by real GDP growth in percent. The economic digitization indicator is measured by the number of internet users (ED1) in percent, the number of social media users (ED2) in a million, and the average internet network speed (ED3) in MBps. The data used in this study is secondary data, namely data on the development of economic digitization, international trade, financial inclusion, and economic growth in the Southeast Asia region obtained from world bank publications, with a period of 2017-2019.

\section{FINDINGS AND DISCUSSION} Impulse Response Function

Analysis Impulse Response Function (IRF) was performed to analyze the speed of a variable in response to the shock of other variables. The response of international trade is due to the shock in the development of economic digitalization in the Southeast Asia region seen in graph 1.

International trade did not respond to a shock in the number of internet users (ED1) until the sixth year of the shock. Just starting in the seventh year, the international trade response has been negative and permanent. The shocks of the number of social media users (ED2) responded positively and permanently by international trade starting in the second year of the shock. The more social media users, the more international trade transactions are carried out. 

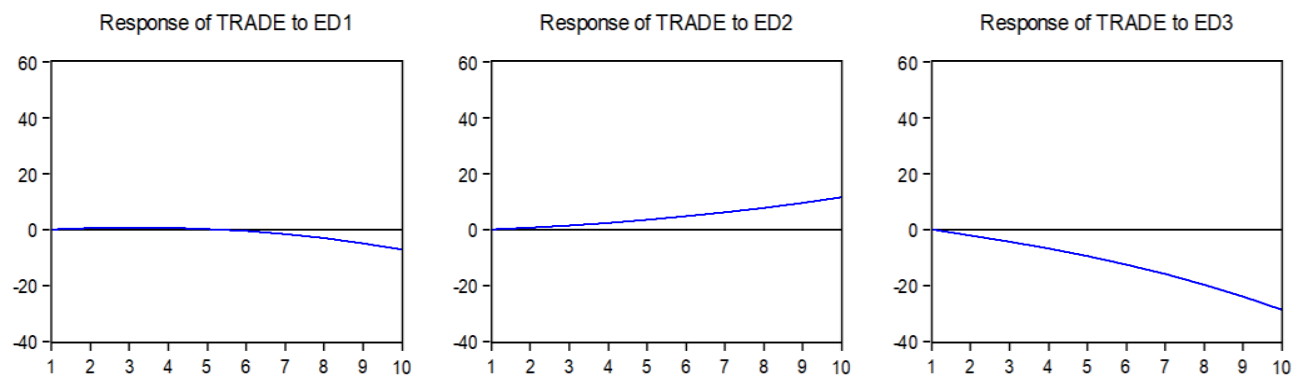

Graph 1. IRF of International Trade

On the other hand, international trade responded negatively and permanently to a shock in the average speed of the internet network (ED3) since the beginning of the year there was a shock. These results indicate that the variables of internet users and the average speed of the internet network have not been sufficient to encourage an increase in international trade. The contributing factor is that a person's decision to buy or sell goods is not caused by the use and speed of the internet network but caused by promotional activities carried out through social media.

Furthermore, how the response to financial inclusion due to the shock in the development of economic digitalization in the Southeast Asia region is seen in graph 2. The results of the IRF analysis show that the shock to all-digital economy variables permanently negatively responded to by financial inclusion variables since the beginning of the period.
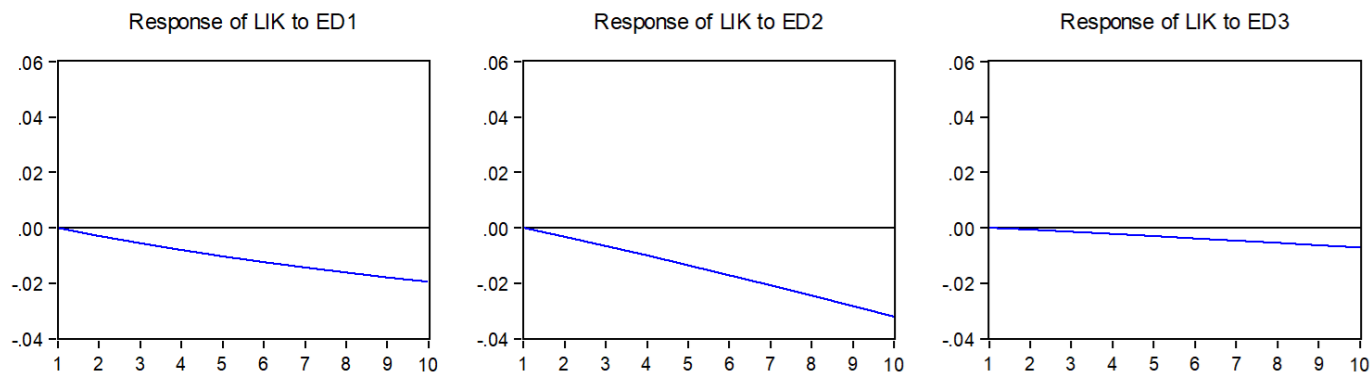

Graph 2. IRF of Financial Inclusion

Inclusion indicators reflecting the financial activities of the banking sector show that economic digitization has a negative impact on the banking sector. The non-bank financial sector development and information technology development can shift the dominance of banks in the financial sector. Innovative financial technology (fintech) provides easy access, convenience, economic costs, and practicality. Fintech is present when there are various kinds of problems that the conventional financial industry cannot serve. Among them are too strict regulations and the limitations of banks in reaching services in certain areas. People who are far from access to banking tend not served by banks. The presence of fintech allows remote communities to access financial services without having to travel long distances. 

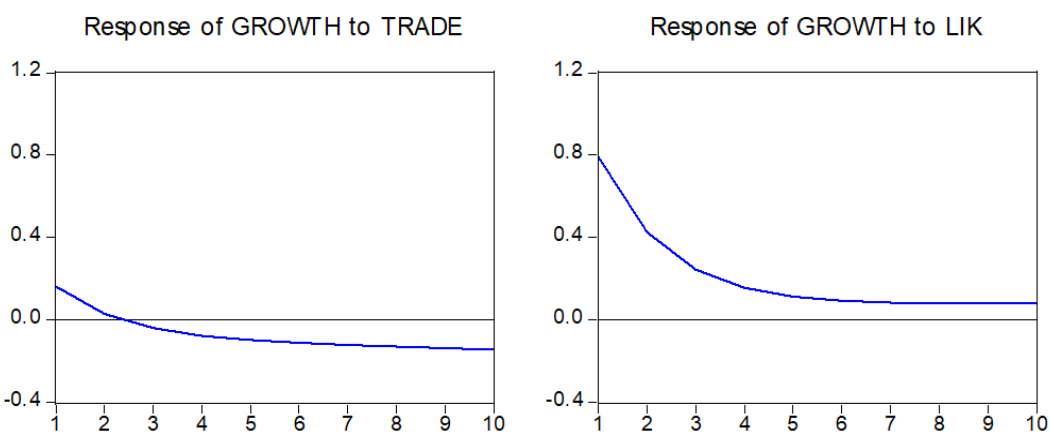

Graph 3. IRF of Economic Growth

The latest response speed of economic growth due to the shock to international trade and financial inclusion in the Southeast Asia region can be seen in graph 3. In the first two years, the shock in international trade can be responded to positively by economic growth. However, in the third year, the shock in international trade responded negatively and permanently to economic growth. This condition shows that international trade can encourage economic growth at the beginning of the period. An increasingly open economy means that exports and imports can increase rapidly. An increase in imports that exceeds an increase in exports can worsen conditions in the domestic economy, reflected in lower economic growth. Economic growth responds positively and permanently to shocks in the financial inclusion variable.

\section{Analysis of Variant Decomposition}

This analysis shows how much one variable can support changes that occur in other variables. The results showed that the variables in the model were more dominantly determined by the variable themselves than other variables in the VAR model.

Table 2. Variant Decomposition: Model 1

\begin{tabular}{cccccc}
\hline \hline \multirow{2}{*}{ Period } & \multicolumn{5}{c}{ Variance Decomposition of TRADE: } \\
& SE. & TRADE & ED1 & ED2 & ED3 \\
\hline \hline 1 & 13.07739 & 100.0000 & 0.000000 & 0.000000 & 0.000000 \\
2 & 20.01573 & 98.73398 & 0.068746 & 0.110388 & 1.086885 \\
3 & 26.72254 & 96.27674 & 0.114306 & 0.363331 & 3.245624 \\
4 & 33.81652 & 93.08995 & 0.106326 & 0.735267 & 6.068454 \\
5 & 41.60519 & 89.49521 & 0.072803 & 1.195310 & 9.236677 \\
6 & 50.31709 & 85.71122 & 0.061255 & 1.711133 & 12.51639 \\
7 & 60.16108 & 81.88657 & 0.116370 & 2.252686 & 15.74437 \\
8 & 71.34838 & 78.12280 & 0.269784 & 2.794344 & 18.81307 \\
9 & 84.10296 & 74.48922 & 0.537479 & 3.315891 & 21.65741 \\
10 & 98.66781 & 71.03213 & 0.921346 & 3.802674 & 24.24385 \\
\hline \hline
\end{tabular}


Table 3. Variants Decomposition: Model 2

\begin{tabular}{cccccc}
\hline \hline & \multicolumn{5}{c}{ Variance Decomposition of LIK: } \\
Period & SE. & LIK & ED1 & ED2 & ED3 \\
\hline \hline 1 & 0.050882 & 100.0000 & 0.000000 & 0.000000 & 0.000000 \\
2 & 0.072916 & 99.62656 & 0.166060 & 0.197540 & 0.009842 \\
3 & 0.090629 & 98.81211 & 0.498239 & 0.656470 & 0.033179 \\
4 & 0.106343 & 97.61787 & 0.945497 & 1.366895 & 0.069733 \\
5 & 0.120957 & 96.09998 & 1.467773 & 2.313575 & 0.118672 \\
6 & 0.134936 & 94.30985 & 2.033998 & 3.477398 & 0.178749 \\
7 & 0.148558 & 92.29450 & 2.620396 & 4.836678 & 0.248428 \\
8 & 0.162004 & 90.09669 & 3.209043 & 6.368265 & 0.326003 \\
9 & 0.175399 & 87.75513 & 3.786692 & 8.048486 & 0.409693 \\
10 & 0.188837 & 85.30458 & 4.343801 & 9.853900 & 0.497721 \\
\hline \hline
\end{tabular}

Table 4. Varian Decomposition: Model 3

\begin{tabular}{ccccc}
\hline \hline \multicolumn{5}{c}{ Variance Decomposition of GROWTH: } \\
Period & SE. & GROWTH & TRADE & LIK \\
\hline \hline 1 & 1.416310 & 100.0000 & 0.000000 & 0.000000 \\
2 & 1.599435 & 99.87449 & 0.121433 & 0.004079 \\
3 & 1.652601 & 99.60162 & 0.385904 & 0.012472 \\
4 & 1.673526 & 99.21178 & 0.764477 & 0.023743 \\
5 & 1.685416 & 98.73364 & 1.229711 & 0.036650 \\
6 & 1.694682 & 98.18537 & 1.764231 & 0.050397 \\
7 & 1.703354 & 97.57624 & 2.359241 & 0.064521 \\
8 & 1.712190 & 96.90992 & 3.011317 & 0.078762 \\
9 & 1.721538 & 96.18701 & 3.720029 & 0.092963 \\
10 & 1.731596 & 95.40644 & 4.486535 & 0.107022 \\
\hline \hline
\end{tabular}$==$

\section{Granger Causality Test}

Based on the test Granger causality in table 5, there are One-way and two-way causality between international trade variables and economic digitization indicator variables, namely the number of internet users (ED1), the number of social media users (ED2), and the average speed of the internet network (ED3). This shows that a person's decision in conducting international trade transactions is not caused by the ease of transactions through the development of information technology but is caused by other factors such as prices, tastes, and income.

Table 5. Granger Causality Test: Model 1

\begin{tabular}{ccc}
\hline \hline Null Hypothesis: & F-Statistic & Prob. \\
\hline \hline ED1 does not Granger Cause TRADE & 4.23997 & 0.1027 \\
TRADE does not Granger Cause ED1 & 0.16488 & 0.8535 \\
\hline \hline ED2 does not Granger Cause TRADE & 0.01049 & 0.9896 \\
TRADE does not Granger Cause ED2 & 0.20446 & 0.8231
\end{tabular}




\begin{tabular}{ccc} 
ED3 does not Granger Cause TRADE & 2.12402 & 0.3201 \\
TRADE does not Granger Cause ED3 & 0.10382 & 0.9059 \\
\hline
\end{tabular}

However, the digitalization of the economy with variable indicators of the number of internet users (ED1), the number of social media users (ED2) can affect financial inclusion. The rapid development of information technology has changed the pattern and access to financial institutions. The increase in financial inclusion has also affected the improvement of information technology infrastructure as measured by the average speed of the internet network. More and more people involved in financial activities are demanding improvements to their supporting infrastructure (Table 6).

Table 6. Granger Causality Test: Model 2

\begin{tabular}{|c|c|c|}
\hline Null Hypothesis: & F-Statistic & Prob. \\
\hline ED1 does not Granger Cause IK & 16.7733 & 0.0113 \\
\hline IK does not Granger Cause ED1 & 0.68617 & 0.5544 \\
\hline ED2 does not Granger Cause IK & 5.48574 & 0.0714 \\
\hline IK does not Granger Cause ED2 & 3.53348 & 0.1306 \\
\hline ED3 does not Granger Cause IK & 0.23013 & 0.8129 \\
\hline IK does not Granger Cause ED3 & 48.2929 & 0.0203 \\
\hline \multicolumn{3}{|c|}{ Table 7. Granger Causality Test: Model 3} \\
\hline Null Hypothesis: & F-Statistic & Prob. \\
\hline GROWTH does not Granger Cause TRADE & 0.59019 & 0.5962 \\
\hline TRADE does not Granger Cause GROWTH & 2.65062 & 0.1849 \\
\hline GROWTH does not Granger Cause IK & 0.96137 & 0.4561 \\
\hline IK does not Granger Cause GROWTH & 10.2271 & 0.0268 \\
\hline
\end{tabular}

Based on the causality test in table 7, there is no causal relationship between international trade and economic growth in ten ASEAN countries. Economic openness has not been able to become an engine of growth in the ASEAN region. The economy is mainly supported by the domestic market, both from the seller and buyer's sides. However, the existence of financial inclusion can affect economic growth. Thus, to encourage economic growth in ten ASEAN countries, it is necessary to increase financial inclusion through increasing access to finance through banks and non-bank financial institutions.

\section{CONCLUSION AND FURTHER RESEARCH}

Variables of international trade and financial inclusion can respond quickly to shocks in the variable of economic digitization. Furthermore, economic growth can respond quickly to shocks in global trade variables and financial inclusion variables. There is no causal relationship between economic growth and international trade. However, there is a one-way causal relationship between economic growth and financial inclusion, where inclusion affects economic growth but not vice versa. 
Economic digitization is necessary, and government policies are needed to develop the digital economy through regulations and improvement of supporting infrastructure while still paying attention to aspects of consumer protection. International trade is not sufficient to encourage economic growth. The strengthening of the domestic economy is more focused on increasing production efficiency and productivity that is oriented towards the domestic market. Financial inclusion can influence economic growth so that strengthening financial inclusion on the demand and supply side must continue to carry out through the synergy of the government and the private sector. In the following research, it is necessary to add any other variables of economic digitalization. Furthermore, conduct a comparative study of the effects of economic digitization in developed and developing countries.

\section{ACKNOWLEDGEMENT}

The authors would like to thank the Institute for Research and Community Service at Universitas Pembangunan Nasional Veteran Yogyakarta, Indonesia, for providing funds for this research.

\section{REFERENCES}

Ahmedov (2020). The Impact of Digital Economy on International Trade. EJBMR, European Journal of Business and Management Research, 5(4), 1-7.

Amuso, V., Poletti, G., \& Montibello, D. (2019). The Digital Economy: Opportunities and Challenges. Global Policy, 11(1), 124-127. https://doi.org/10.1111/1758-5899.12745.

Bilozubenko, V., et al. (2020). Comparison of the digital economy development parameters in the EU countries in bridging the digital divide. Problems and Perspectives in Management, 18(2), 206-218. doi:10.21511/ppm.18(2).2020.18.

Ciuriak, D. and Maria Ptashkina (2018). The Digital Transformation and the Transformation of International Trade. RTA Exchange. Geneva: International Center for Trade and Sustainable Development (ICTSD) and Inter-American Development Bank (IDB).

Gujarati, Damodar N (2012), Econometrics by Examples, Palgrave Macmillan, New York.

Gujarati, Damodar N and Dawn C Porter (2009), Basic Econometrics, 5th Edition, McGraw-Hill, Singapore.

Myovella, G., Karacuka, M., \& Hakata, J. (2020). Digitalization and economic growth: A comparative analysis of Sub-Saharan Africa and OECD economies. Telecommunications Policy, 44(2). https://doi.org/10.1016/j.telpol. 2019.101856.

Njoh, AJ (2018). The relationship between modern Information and Communications Technologies (ICTs) and development in Africa. Utilities Policy, 50, 83-90.https://doi.org/10.1016/j.jup.2017.10.005.

Pereira, A., \& Romero, F. (2017). A review of the meanings and the implications of the Industry 4.0 concept. Procedia Manufacturing, 13, 1206-1214. https://doi.org/ 10.1016/j. promfg. 2017.09.032.

Semyachkov, KA (2019). The digital economy in developing countries: problems and prospects. Advances in Economics, Business and Management Research, volumes 81, 102-106.

Wang, Z. (2021). Research on Digital Economy and Human Resources Based on Fuzzy Clustering and Edge Computing. Security and Communication Networks, Volume 2021, Article ID 5583967, 8 pages. https://doi.org/10.1155/2021/5583967. 